\title{
Effect of cosmetic films with ascorbic acid and hyaluronic acid on transepidermal water loss
}

\author{
Efeito de filmes cosméticos com ácido ascórbico e ácido hialurônico na perda \\ de água transepidermal
}

\author{
Isadora Marques Garros Brait ${ }^{1}$, Mariane Massufero Vergilio ${ }^{2}$, Laura Moretti Aiello ${ }^{1}$, \\ Gislaine Ricci Leonardi ${ }^{1^{*}}$
}

\begin{abstract}
${ }^{1}$ School of Pharmaceutical Sciences-University of Campinas (UNICAMP), 200, Cândido Portinari St., "Cidade Universitária Zeferino Vaz", 13083-871-Campinas, SP, Brazil; ${ }^{2}$ Graduate Program in Internal Medicine, School of Medical Sciences - University of Campinas (UNICAMP), 126, Tessália Vieira de Camargo St., "Cidade Universitária Zeferino Vaz", 13083-887-Campinas, SP, Brazil.
\end{abstract}

*corresponding author / autor para correspondência: gislaine.leonardi@fcf.unicamp.br

\begin{abstract}
Cosmetic films are structures made of a polymer capable of forming a continuous matrix. Collagen and hyaluronic acid (HA) are components of the skin extracellular matrix and act to maintain its elasticity and resistance. Ascorbic acid (AA) acts in the formation of collagen fibers, contributing to the maintenance of their firmness and elasticity. This study aimed to evaluate the moisturizing properties of cosmetic films with AA or HA in their composition. It was also investigated whether the presence of caprylyl glycol would interfere with the TWEL of the formulations. The occlusive properties of the films were assessed based on the reduction of transepidermal water loss (TEWL) in 20 healthy participants using a Tewameter probe. At T30, 30 minutes after application, all formulations showed a reduction in TEWL compared to the control. In general, the formulations that included caprylyl glycol presented the best TEWL results after 30 min of application. However, after 60 minutes, the transepidermal water loss began to return to its basal levels. This study showed a significant difference in the TEWL value, suggesting that the topical application of the films can contribute to the improvement and maintenance of skin hydration.
\end{abstract}

Keywords: cosmetic films; collagen; hyaluronic acid; ascorbic acid; skin barrier

\section{Resumo}

Filmes cosméticos são estruturas constituídas de um polímero capaz de formar uma matriz contínua. O colágeno e o ácido hialurônico $(\mathrm{AH})$ são componentes da matriz extracelular da pele e atuam mantendo sua elasticidade e resistência. $\mathrm{O}$ ácido ascórbico (AA) atua na formação das fibras de colágeno, contribuindo para a manutenção de sua firmeza e elasticidade. Este estudo teve como objetivo avaliar as propriedades hidratantes de filmes cosméticos com AA, ou AH em sua constituição. Investigou-se também se a presença de caprilil glycol interferiria no TWEL das formulações. As propriedades oclusivas dos filmes foram avaliadas com base na redução da perda de água transepidérmica (TEWL) em 20 participantes saudáveis com o auxílio da sonda Tewameter. No T30, todas as formulações apresentaram redução na TEWL após 30 minutos de aplicação em relação ao controle. Entretanto, após 60 minutos, a TEWL começou a retornar aos seus níveis basais. Em geral, as formulações adicionadas com Caprilil Glicol, foram as que apresentaram os melhores resultados de TEWL. Este estudo mostrou uma diferença significativa no valor de TEWL, sugerindo que a aplicação tópica dos filmes podem contribuir para a melhora e manutenção da barreira cutânea.

Palavras-chave: Filmes cosméticos; colágeno; ácido hialurônico; ácido ascórbico; barreira cutânea 


\section{Introduction}

The presence of water in the skin is essential for all the body metabolic activities, its mechanical properties such as elasticity and turgidity (1), and therefore considered essential to the skin (2). Skin dehydration, in addition to initiating inflammatory processes, can lead to scaling, cracking, tension, redness, bleeding, sagging, and a worsening in the overall appearance of the skin (2).

Healthy skin remains hydrated by regulating the production of intracellular lipids and the natural moisturizing factor (NMF), which work by promoting the maintenance of water in the epidermis and dermis. However, factors such as water intake, hormone levels, metabolism, aging, and stress can affect hydration $(1,2,3)$.

Moisturizing cosmetics can promote skin hydration, increasing the aqueous content of the stratum corneum or promoting the maintenance of water in this layer $(2,3,4)$. This occurs due to humectant components, hygroscopic molecules that operate by attracting water to the upper layers of the skin, emollients, which fill the empty spaces between corneocytes, promoting a soft sensation, as well as occlusive agents, which prevent transepidermal water loss (TEWL) $(3,4)$.

Several types of cosmetic formulations are developed to prevent and reverse skin dryness. Among them, cosmetic films are an innovative topical system, consisting of a polymer capable of forming a continuous matrix with a compact format, which allows the storage and transport of assets, with fewer inconveniences, in addition to being a biodegradable option (5). Currently, this system has also been widely used by the pharmaceutical industry in the production of transdermal drug delivery systems, dressings, and molds for tissue growth for the treatment of burns (6), by the industry of foods in the preservation of their products (7), and by the cosmetic industry to improve the performance of developed products.

\section{Introdução}

A presença de água na pele é essencial para todas as atividades metabólicas do organismo suas propriedades mecânicas, como elasticidade e turgidez (1), e, portanto, consideravelmente importante para a saúde da pele (2). A desidratação cutânea, além de iniciar processos inflamatórios, pode gerar descamação, fissuras, tensão, vermelhidão, sangramentos, flacidez e uma piora na aparência geral da pele (2).

A pele saudável se mantém hidratada através da regulação da produção de lipídios intracelulares e do fator de hidratação natural (Natural moisturizing factor - NMF), que atuam promovendo a manutenção da água na epiderme e derme. No entanto, fatores como ingestão de água, níveis hormonais, metabolismo, envelhecimento e estresse podem afetar a hidratação $(1,2,3)$.

Cosméticos hidratantes são capazes de promover a hidratação cutânea, aumentando o conteúdo aquoso do estrato córneo ou promovendo a manutenção da água nesta camada $(2,3,4)$. Isto ocorre devido aos componentes umectantes, moléculas higroscópicas que atuam atraindo a água para às camadas superiores da pele, emolientes, que preenchem os espaços vazios entre os corneócitos, promovendo uma sensação de maciez, bem como os agentes oclusivos, que impedem a perda de água transepidermal $(3,4)$.

Neste contexto, diversos tipos de formulações cosméticas são desenvolvidos com o objetivo de prevenir e reverter o ressecamento da pele. Entre eles, os filmes cosméticos são um sistema tópico inovador, constituído por um polímero capaz de formar matriz contínua de formato compacto, que permite o armazenamento e transporte de ativos, com menores inconvenientes, além de ser uma opção biodegradável (5). Atualmente, esse sistema também tem sido bastante utilizado pela indústria farmacêutica na produção de sistemas de liberação transdérmica de fármacos, curativos e moldes para crescimento tecidual, além de auxiliar no tratamento de queimaduras (6), assim como pela indústria de alimentos na conservação de seus produtos (7), e a tecnologia foi transferida para a indústria cosmética para melhorar a performance de produtos desenvolvidos.

O colágeno é um biopolímero estrutural responsável pela constituição da pele, ossos, vasos sanguíneos, matriz extracelular, dentes e cartilagens (8). Na pele ele é responsável pela elasticidade e resistência, como um dos principais constituintes da matriz extracelular, sua 
Collagen is a structural biopolymer responsible for the constitution of skin, bones, blood vessels, extracellular matrix, teeth, and cartilage (8). In the skin, it is responsible for elasticity and resistance. As one of the main constituents of the extracellular matrix, its loss or reduction results in aging is signaled by the appearance of wrinkles and expression lines $(9,10)$. Molecules or fibers of collegen protein can form hydrogels, films, or sponges that can be used as hemostatic agents, dressings, grafts, and molds for surgery and tissue growth (6).

Like collagen, hyaluronic acid (HA) is a component of the skin's extracellular matrix (11), responsible for its firmness, turgor, and hydration, due to its ability to attract water molecules to this skin layer $(10,12)$. During the aging process, levels of HA in the skin decrease $(10,12)$. Its topical use is proven to be beneficial in healing processes, promoting faster and more uniform healing without causing deformities in the damaged skin $(11,12,13,14)$.

Ascorbic acid (AA), or vitamin C, is an antioxidant and water-soluble molecule obtained through food or topical application (9). The latter has been shown to have more expressive effect in reducing spots on the skin than food supplementation, as observed in a study by Imai et al. (15). This vitamin also acts in the formation of collagen fibers in almost all structures, promoting the renewal of the skin barrier and thus contributing to the maintenance of its firmness and elasticity (9).

Caprylyl glycol is a diol that can act as an antimicrobial agent in cosmetic formulations due to its ability to destabilize the bacterial cell membrane. In the skin, it acts as a conditioning, emollient agent, filling the spaces between the corneocytes and making the skin softer, and as a humectant, attracting water molecules to the upper layers of the skin without generating hypersensitivity or irritation in humans $(2,3,4,16,17)$.

To quantitatively assess the in vivo efficacy of cosmetic formulations and raw materials when applied to the skin, several important skin bioengineering techniques are used, including the measurement of the TEWL. TEWL is a natural process that occurs due to the gradient of water concentration between the layers of the skin, causing water to migrate from the deeper layers to the stratum corneum, where it is lost through evaporation (18). This property is one of the most important indicators of the integrity and functionality of the skin barrier, as the value of TEWL increases in damaged or destabilized skin (18). perda ou diminuição resulta no envelhecimento sinalizado pelo surgimento de rugas e linhas de expressão $(9,10)$. Moléculas ou fibras desta proteína podem formar hidrogéis, filmes ou esponjas que podem ser utilizados como agentes hemostáticos, curativos, enxertos e moldes para cirurgias e crescimento tecidual (6).

Assim como o colágeno, o ácido hialurônico (AH) também é um componente da matriz extracelular da pele (11), sendo é responsável por sua firmeza, turgor e hidratação, o que ocorre devido a sua capacidade de atrair as moléculas de água para esta camada $(10,12)$. Durante o processo de envelhecimento a quantidade de AH presente na pele diminui $(10,12)$. Seu uso tópico é comprovadamente benéfico em processos de cicatrização, os quais acontecem mais rápido e de maneira mais uniforme sem causar deformações na pele lesada $(11,12,13,14)$.

O ácido ascórbico (AA), ou vitamina C, é uma molécula antioxidante e hidrossolúvel, que é obtida através da alimentação ou aplicação tópica (9), sendo que este último apresenta um efeito mais expressivo na redução de manchas na pele do que a complementação alimentar, como observado no estudo realizado por Imai et al (15). Esta vitamina também atua na formação das fibras de colágeno em quase todas as estruturas, promovendo renovação da barreira cutânea e, assim, contribuindo com a manutenção de sua firmeza e elasticidade (9).

O caprilil glicol é um diol que nos cosméticos pode atuar como antimicrobiano, devido a sua capacidade de desestabilizar a membrana celular bacteriana, e na pele age como agente condicionador, emoliente, preenchendo os espaços entre os cornócitos e tornando a pele mais macia, e umectante, atraindo as moléculas de água para as camadas superiores da pele, sem gerar hipersensibilidade ou irritação em humanos $(2,3,4,16,17)$.

Para realizar a avaliação da eficácia in vivo de formulações e matérias-primas cosméticas, são utilizadas diversas técnicas de bioengenharia cutânea importantes para mensurar quantitativamente a performance do cosmético quando aplicado na pele. A mensuração da perda de água transepidermal (em inglês, transepidermal water loss - TEWL) é um deles. O TEWL é um processo natural que ocorre devido ao gradiente de concentração de água entre as camadas da pele, fazendo com que a água migre das camadas mais profundas para o estrato córneo, onde é perdida por evaporação (18). Esta propriedade é um dos indicadores mais importantes da integridade e funcionalidade da barreira cutânea, visto que o valor deste parâmetro aumenta em uma pele lesionada ou desestabilizada (18). 
Table 1 - Cosmetic formulations components and concentrations.

Tabela 1 - Componentes e concentração das formulações desenvolvidas.

\begin{tabular}{|c|c|c|c|c|c|}
\hline Components / Componentes & $\mathrm{FcB}_{1}(\%)$ & $\operatorname{FcAA}_{1}(\%)$ & $\mathrm{FcB}_{2}(\%)$ & $\mathrm{FcAH}_{1}(\%)$ & \\
\hline Collagen / Colágeno & 20.00 & 20.00 & 20.00 & 20.00 & \\
\hline Citric Acid / Ácido cítrico & 0.75 & 0.75 & -- & -- & \\
\hline Ascorbic acid / Ácido ascórbico & -- & 0.50 & -- & -- & \\
\hline Hyaluronic acid / Ácido hialurônico & -- & -- & -- & 0.50 & \\
\hline Caprylyl glycol / Caprilil glicol & 1.00 & 1.00 & -- & -- & \\
\hline Glycerin / Glicerina & 8.00 & 8.00 & 8.00 & 8.00 & $\begin{array}{c}\text { FCB2 collagen film produced by } \\
\text { the casting method./ }\end{array}$ \\
\hline Sodium metabisulfite / Metabissulfito de sódio & 1.00 & 1.00 & -- & -- & Filme de colágeno FcB2 produzida \\
\hline Water / Áqua & $q s^{*}$ & $\mathrm{qs}^{*}$ & $\mathrm{qs}^{*}$ & $\mathrm{qs}^{*}$ & \\
\hline
\end{tabular}

Therefore, this study aimed to evaluate the moisturizing properties of cosmetic films composed of collagen, ascorbic acid, and hyaluronic acid by measuring TEWL with the aid of the skin bioengineering technique using a Tewameter ${ }^{\circledR}$ TW 210 probe (Courage-Khazaka electronic $\mathrm{GmbH}$, Germany), coupled with the Multi Probe Adapter MPA 5 software.

\section{Materials and Methods}

\section{Materials}

In the development of cosmetic films, collagen (Gelita, Sao Paulo, BR), citric acid (Synth, Diadema, BR), ascorbic acid (Synth, Diadema, BR), hyaluronic acid (DSM, Sao Paulo, BR), caprylyl glycol (Fagron, São Paulo, BR), glycerin (Fagron, Sao Paulo, BR) and sodium metabisulfite (Synth, Diadema, BR) were used.

\section{Development of cosmetic films}

The preparation of four cosmetic formulations containing (or not) ascorbic acid and hyaluronic acid is summarized in Table 1. The formulations $\mathrm{FcB}_{1}$ and FcAA, without and with ascorbic acid, respectively, also contained caprylyl glycol. The cosmetic films (Table 1, inset) were prepared by casting method involving the addition of a filmogenic solution on a silicone surface followed by solvent evaporation at a constant temperature of $40{ }^{\circ} \mathrm{C}(19)$.
Sendo assim, este estudo teve como objetivo avaliar as propriedades hidratantes de filmes cosméticos compostos por colágeno, ácido ascórbico e ácido hialurônico, com o auxílio da técnica de bioengenharia cutânea o auxílio da sonda Tewameter TW 210, produzida pela empresa Courage-Khazaka electronic $\mathrm{GmbH}$, Alemanha, acoplada ao software Multi Probe Adapter MPA 5 utilizada para mensurar a perda de água transepidermal (TEWL).

\section{Material e Métodos}

\section{Materiais}

No desenvolvimento dos filmes cosméticos foram utilizados colágeno (Gelita, São Paulo, BR), ácido cítrico (Synth, Diadema, BR), ácido ascórbico (Synth, Diadema, BR), ácido hialurônico (DSM, São Paulo, BR), caprilil glycol (Fagron, São Paulo, BR), glicerina (Fagron, São Paulo, BR) e metabissulfito de sódio (Synth, Diadema, BR).

\section{Desenvolvimento dos filmes cosméticos}

Quatro formulações cosméticas contendo ou não ácido ascórbico ou ácido hialurônico, foram preparadas de acordo com a Tabela 1. As formulações $\mathrm{FcB}_{1}$ e FcAA, respectivamente não adicionada e adicionada de ácido ascórbico, também continham caprilil glicol. Os filmes cosméticos (Tabela 1, inset) foram preparadas de acordo com o método casting, que consistiu em adicionar à solução filmogênica a uma superfície de silicone para evaporação do solvente a temperatura constante de $40{ }^{\circ} \mathrm{C}$ (19). 
Figure 1 - Illustration of a participant's forearm with the markings of the fields used to apply the tested products, in which X represents the distance between the wrist or elbow and the closest field of application. (Source: Envato elementos - modified by author).

Figura 1 - Ilustração do antebraço de um participante com as marcações dos campos utilizados para aplicação dos produtos testados, na qual X representa a distância entre o pulso ou o cotovelo e o campo de aplicação mais próximo. (Fonte: Envato elementos - modificada pelo autor).

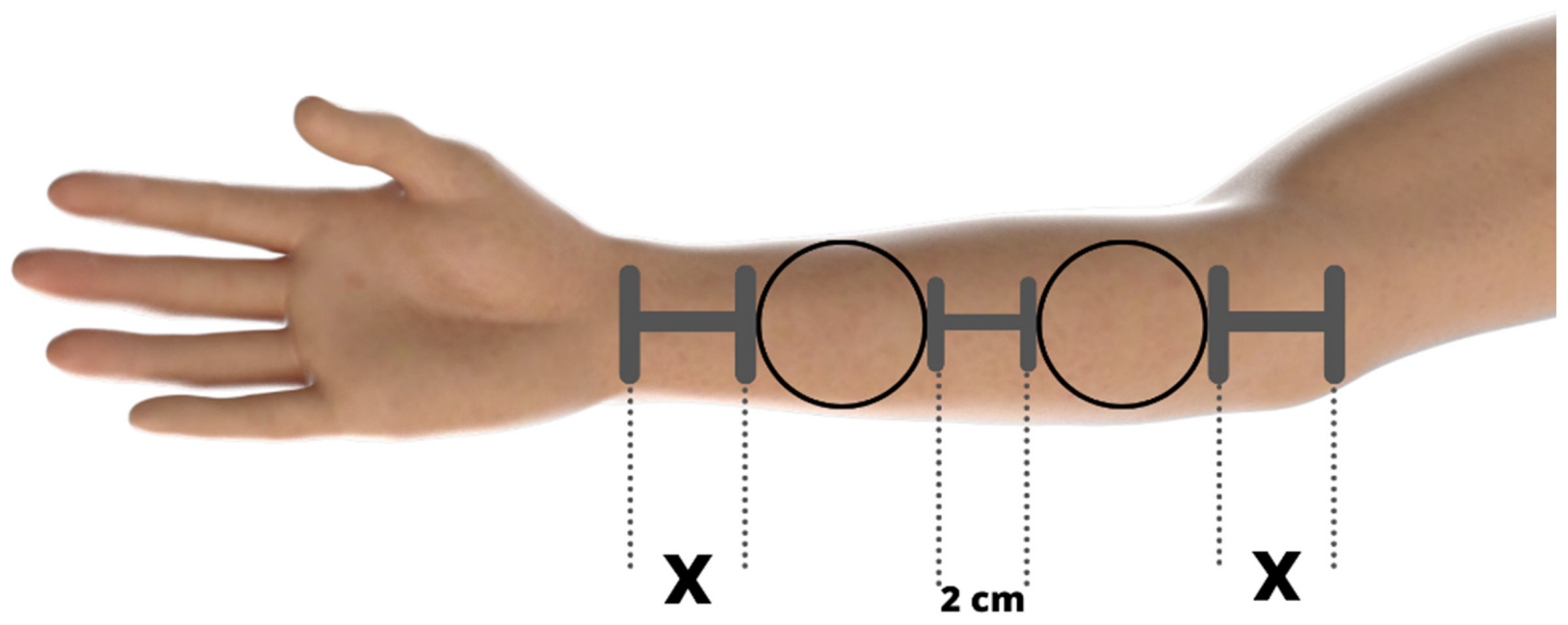

In vivo efficacy assessment

\section{Experimental design}

This study was approved by the Research Ethics Committee of the School of Medical Sciences at Unicamp (CAAE: 13367219.5.0000.5404), and all participants signed forms to confirm informed consent. A total of 20 participants were included in the study according to the inclusion criteria, specifically, healthy participants aged between 20 and 60 years with the ability to understand and follow the guidelines, including not washing or applying any cosmetic products to the test region of the skin for at least two hours prior to testing. Exclusion criteria included the lack of understanding of the method to be used or presence of lesions compatible with active infectious diseases. The study was conducted in double-blind manner in a temperature-controlled room. The subjects were acclimated 20 minutes before starting instrumental measurements (20).

Five randomized sites with $16 \mathrm{~cm}^{2}$ of area were marked on the volar forearms of each participant. The distance between the sites was $2 \mathrm{~cm}$, as illustrated in Figure 1 . As the formulations must be moistened to dissolve and release the active ingredients (5), the marked areas were moistened with ten drops of water before applying the films. The films were then randomly applied to the moistened regions by an independent researcher and removed after 15 minutes. Formulation residues were
Avaliação da eficácia in vivo

\section{Protocolo experimental}

O estudo foi aprovado pelo Comitê de Ética da Faculdade de Ciências Médicas da Unicamp (CAAE: 13367219.5.0000.5404), e todos os participantes assinaram do Termo de Consentimento Livre e Esclarecido. Um total de 20 participantes foram incluídos no estudo de acordo com os critérios de inclusão, participantes saudáveis com idade entre 20 e 60 anos com capacidade de compreender e seguir as orientações e não lavar ou aplicar nenhum produto cosmético a região da pele do teste por pelo menos duas horas antes do teste. Os critérios de exclusão incluíam a falta de compreensão do método a utilizar ou a presença de lesões compatíveis com doenças infecciosas activas. $\mathrm{O}$ estudo duplo-cego foi realizado em uma sala com temperatura controlada. Os participantes foram aclimatados 20 minutos antes do início das medidas instrumentais (20).

De mandeira aleatorizada, cinco campos com 16 $\mathrm{cm}^{2}$ foram demarcadas no antebraço anterior de cada participante, a distância entre os campos foi de $2 \mathrm{~cm}$ (Figura 1). Para que as formulações sejam dissolvidas e possam liberar seus ativos que os filmes devem ser umedecidos (5) assim, antes da aplicação das formulações, as áreas demarcadas foram umedecidas com dez gotas de água. Então, os filmes 
moistened with ten drops of water and spread on the skin for 30 seconds to ensure a more effective and uniform product absorption. Instrumental measurements were performed before (T0) and $30 \mathrm{~min}$ (T30), $60 \mathrm{~min}$ (T60) after application of the films, according to the EEMCO Guidance for the Assessment of TEWL in cosmetics (21).

\section{Transepidermal water loss}

Skin barrier effect was evaluated through Transepidermal Water Loss (TEWL). TEWL measurements were performed as illustrated in Figure 2, using Tewameter TW 210 probe (Courage \& Khazaka, Köln, Germany), whose function is to measure the transepidermal water loss based on the diffusion principle described by Adolf Fick in 1885, adapted by Capitani et al. (22):

$$
d m / d t=-D \times A \times d p / d x
$$

Where $d m / d t$ is the diffusion flux, $A$ is the area, $d c / d x$ is the concentration variation per distance, and $D$ is the diffusion coefficient of water vapor in air. TEWL units are stated as $\mathrm{g} \cdot \mathrm{m}^{-2} \cdot \mathrm{h}^{-1}$. The device probe was placed on the center of outlined skin areas and maintained in position to obtain 25 measurements (Figure 2). foram randomizamente aplicados por um pesquisador independente nos campos umedecidos e removidos após 15 minutos. Os resíduos das formulações foram então umedecidos com 10 gotas de água e espalhados na pele por 30 segundos para garantir uma absorção mais eficaz e uniforme do produto. As leituras instrumentais foram realizadas antes (controle - T0), $30 \mathrm{~min}$ (T30) e $60 \mathrm{~min}$ (T60) após a aplicação, de acordo com o EEMCO Guia para a avaliação de TEWL em cosmetologia (21).

\section{Perda transepidérmica de água}

O efeito de barreira da pele foi avaliado pela perda transepidérmica de água (TEWL). Para a determinação deste parâmetro foi utilizada a sonda Tewameter TW 210 (Courage \& Khazaka, Köln, Alemanha), ilustrada na Figura 2, cuja função é medir a perda transepidérmica de água, baseado no princípio da difusão descrito por Adolf Fick em 1885, adaptado por Capitani et al (22):

$$
d m / d t=-D \times A \times d p / d x
$$

Onde, $d m / d t$ é o fluxo de difusão, $A$ é a área, $d c / d x$ é a alteração de concentração por distância e $D$ é o coeficiente de difusão do vapor de água no ar. Os valores serão fornecidos em g.m $\mathrm{m}^{-2} \cdot \mathrm{h}^{-1}$. A sonda do aparelho foi colocada sobre a pele no centro dos campos demarcados nos antebraços e mantida pelo tempo necessário para a obtenção de 25 medidas (Figura 2). a)

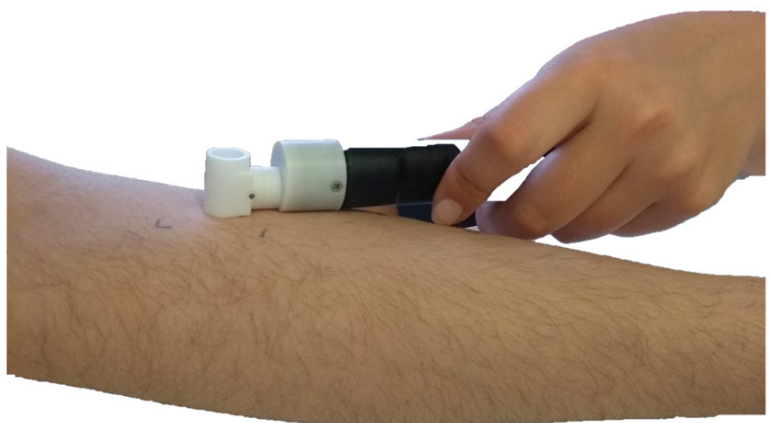

b)

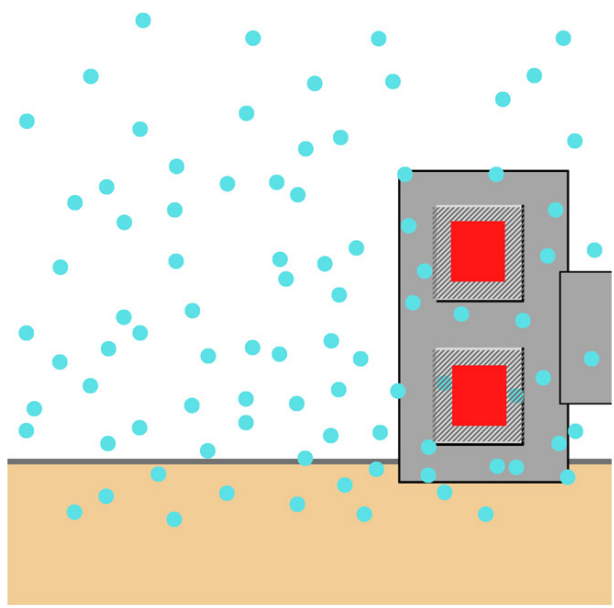

Figure 2 - a) Tewameter TW 210 probe applied to the skin to measure transepidermal water loss. b) Diagram illustrating the capture of transepidermal water loss.

Figura 2 - a) Sonda Tewameter TW 210 aplicada sobre a pele para medida de perda de água transepidermal. b) Diagrama que ilustra a captação da perda de água transepidermal. 


\section{Statistical analysis}

One-way analyses of variance (ANOVA) were applied to test the differences among the formulations $(\alpha=$ 0.05). Tukey's multiple comparison post-test was used to determine the differences among the obtained parameters. A confidence level of $95 \%$ was considered. Analyses were performed in GraphPad Prism 9.2.0 software (GraphPad, San Diego, LA, USA)

In order to compare the effects of different formulations on transepidermal water loss, the differences in the TEWL between the areas in which the films were applied and the control areas were calculated (23):

$$
[(\mathrm{Tn}-\mathrm{T} 0)-(\mathrm{NTn}-\mathrm{NT} 0)]
$$

Where Tn in the TEWL at time n, T30 or T60 T0 is the measure of TEWL at time T0, before application of the formulations, NTn is the measure of TEWL of the control area at time $\mathrm{n}$ and, NT0 is the measure of TEWL of the control area at time T0 (23). The differences were then divided by the value of Transepidermal Water Loss in $\mathrm{T} 0$ to obtain the increment percentage.
Análise estatística

Análises de variância unilateral (ANOVA) foram aplicadas para testar as diferenças entre as formulações $(\alpha=0,05)$. O pós-teste de comparação múltipla de Tukey foi usado para determinar as diferenças entre os parâmetros obtidos. Foi considerado um nível de confiança de $95 \%$ e as análises foram realizadas no GraphPad Prism 9.2.0 software (GraphPad, San Diego, LA, EUA).

Para comparar os efeitos das diferentes formulações na perda de água transepidermal foi realizado o cálculo da diferença da nos valores de perda de água transepidermal (TEWL) entre as áreas nas quais os filmes foram aplicados e as áreas controle (23):

$$
[(\mathrm{Tn}-\mathrm{T} 0)-(\mathrm{NTn}-\mathrm{NT} 0)]
$$

Onde, Tn é o valor de TEWL no tempo $n$, T30 ou T60, T0 é a medida de TEWL no tempo T0, antes da aplicação das formulações, NTn é a medida de TEWL do campo controle no tempo $n$ e NT0 é a medida de TEWL do campo controle no tempo T0 (23). As diferenças foram então divididas pelo valor da perda de gua transepidermal em T0 para obter-se a porcentagem de incremento.

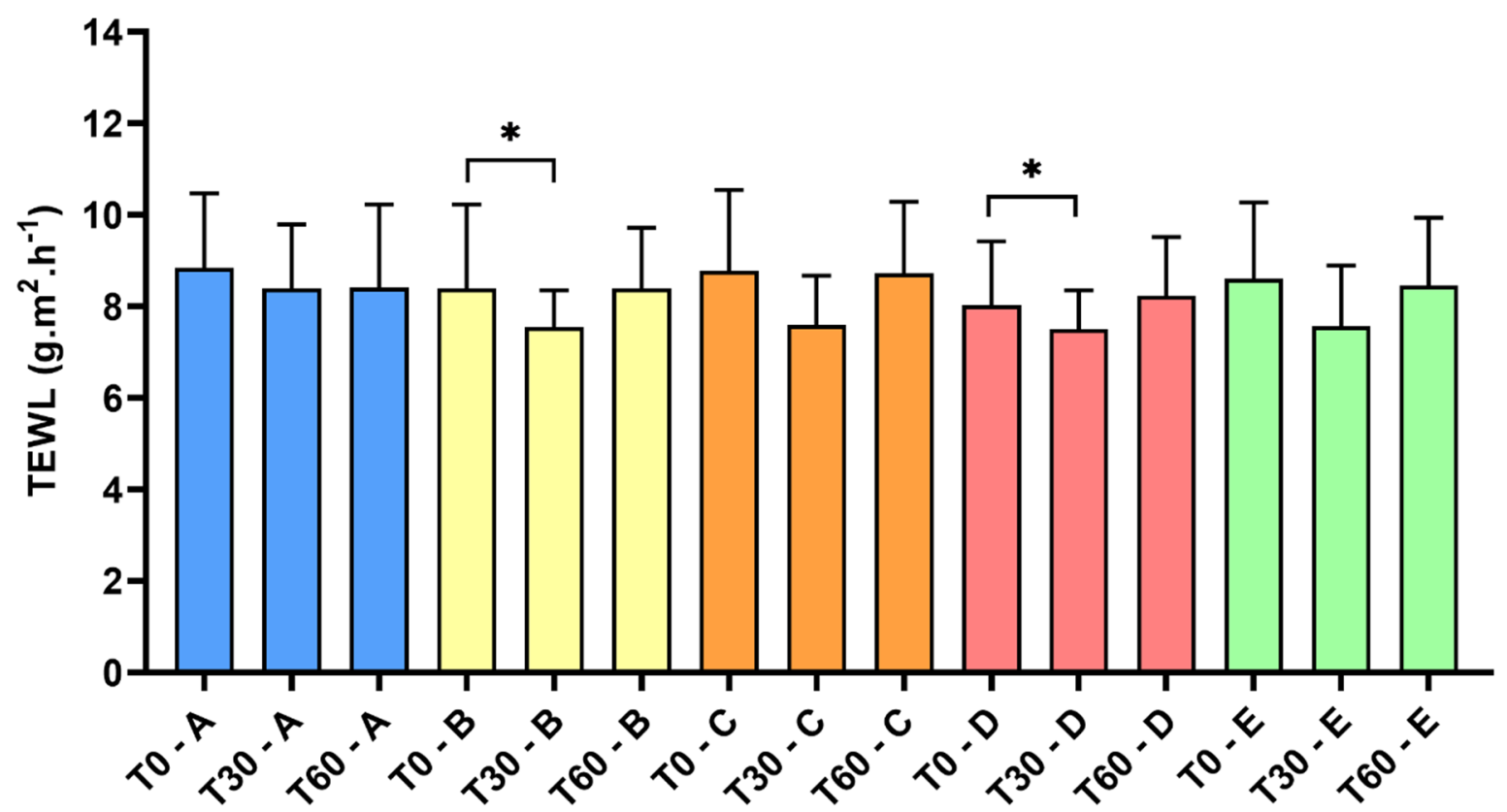

Figure 3 - Mean values of transepidermal water loss (TEWL) of the demarcated areas at times T0, before application, T30 minutes after and T60 minutes after application of the films, where A represents the control area, B, C, D and E represent the areas where the formulation FcB1, FcAA, FcB2 and FcAH, respectively, were applied.

Figura 3 - Médias de perda de água transepidermal (TEWL) das áreas demarcadas nos tempos T0, antes da aplicação, T30, 30 minutos após e T60, 60 minutos após a aplicação dos filmes, onde A representa a área controle, B, C, D e E, representam respectivamente as áreas onde as formulações FcB1, FcAA, FcB2 and FcAH foram aplicadas. 


\section{Results}

The graphs shown in Figures 3 and 4 describe the averages of TEWL and the percentage difference of TEWL, respectively, in the evaluation of the cosmetic films at times T0, before application, and at 30 minutes (T30) and 60 minutes (T60) after application of the different films.

All formulations showed a reduction of at least $-11 \%$ in the range of 0 to 30 minutes compared to the control. After 30 minutes of application, reduced the highest reduction in TEWL was recorded in the FcAA formulation, showing a -23.25 percent difference, followed by the FcB1 formulation, which reduced TEWL by $20.00 \%$. TEWL was reduced $12.5 \%$ and $11 \%$ in the FcAH and FcB2 formulations, respectively.

\section{Resultados}

A perda de água transepidermal (TEWL) foi avaliada com auxílio da sonda Tewameter TW 210, os gráficos apresentados nas Figuras 3 e 4 descrevem as médias de TEWL e a diferença percentual de TEWL, respectivamente na avaliação dos filmes cosméticos nos tempos 0 , antes da aplicação, 30 minutos após a aplicação dos filmes e 60 minutos após a aplicação dos filmes.

Todas as formulações mostraram uma redução de no mínimo $11 \%$ no intervalo de 0 a 30 minutos com relação ao campo controle. A formulação FcAA, foi a formulação que mais reduziu a TEWL, apresentando uma diferença percentual de $23,25 \%$, seguida pela formulação $\mathrm{FcB}_{1}$, que reduziu em $20 \%$. As formulações $\mathrm{FcAH}$ e $\mathrm{FcB}_{2}$, reduziram $12,5 \%$ e $11 \%$ respectivamente, podemos observar que as formulações mais oclusivas apresentaram uma redução no mínimo $60 \%$ maior do que as menos oclusivas neste intervalo de 0 a 30 minutos.

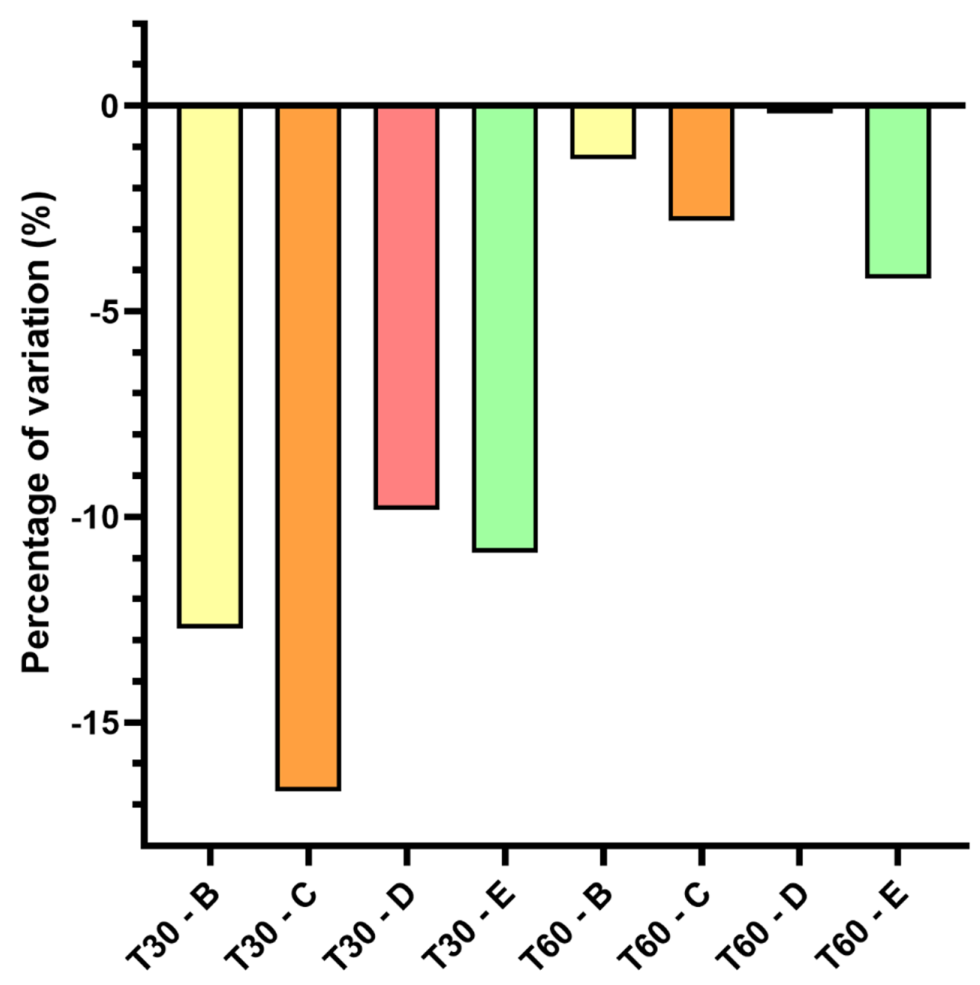

Figure 4 - Percentage difference in transepidermal water loss (TEWL) of the regions where the films were applied in relation to the control region, at times T0, before application, T30, 30 minutes after and T60, 60 minutes after application of the films, where B, C, D and E represent the areas where the formulation FcB1, FcAA, FcB2 and FcAH, respectively, were applied.

Figura 4 - Diferença percentual na perda de água transepidermal (TEWL) das regiões em que foram aplicados os filmes com relação a região controle, nos tempos T0, antes da aplicação, T30, 30 minutos após e T60, 60 minutos após a aplicação dos filmes, onde A representa a área controle, B, C, D e E, representam respectivamente as áreas onde as formulações FcB1, FcAA, FcB2 and FcAH foram aplicadas. 
In the interval between 0 to 60 minutes, the $\mathrm{FcB}_{1}, \mathrm{FcAA}$, and $\mathrm{FcAH}$ formulations continued to show a reduction in TEWL compared to the control, with values of -5.00 , -1.625 and $-0.375 \%$, respectively, while the $\mathrm{FcB} 2$ formulation showed an increase of $1.75 \%$.

\section{Discussion}

The films developed in this work showed a barrier recovery effect demonstrated by the reduction in TEWL $(3,4)$. Cosmetic films are capable to form a continuous matrix with a compact shape on the skin (5) and inhibit TEWL by occlusion; one of the hydration action mechanisms (24). The occlusive moisturizers decrease TEWL by forming a hydrophobic film on the skin surface and contributing to the corneocytes matrix (24).

The formulations including caprylyl glycol, FcB1 and FcAA, resulted in a more pronounced reduction in TEWL in both time intervals, showing better results as moisturizers than the formulations which did not include this ingredient. This TEWL decrease occurs because caprylyl glycol brings fatty material to the film-forming formulation, resulting in emollience and contributing to prevent transepidermal water loss on the skin surface (25). In the skin, the factor that most influences water loss is the composition and organization of lipids in the extracellular domains (26).

The decreased TEWL in the areas treated with formulations including caprylyl glycol or hyaluronic acid can also be explained by their humectant activity $(10,12)$. Those components attract water molecules to the skin surface $(3,4,10,12,16,17,27)$, where they form an emulsion with skin lipids and sweat components, decreasing TEWL (27).

However, after 60 minutes, the TEWL values begin to return to basal levels, possibly due to product absorption. Furthermore, it is known that the reduction in TEWL values by the application of a topical formulation is related to the amount of product, the fatty content. and the lipid type present in the formulation (28). The addition of lipids with carbon chains of longer length provides lower skin barrier permeability and lower TEWL values (29). Thus, given that GC is a fatty alcohol with an intermediate carbon chain length, its emollient effect may have been reduced after a longer period of time (T60).
No intervalo de 0 a 60 minutos, as formulações $\mathrm{FcB}_{1}$, FcAA e FcAH, continuaram a apresentar redução na TEWL com relação ao campo controle de 5, 1,625 e $0,375 \%$, respectivamente, enquanto a formulação $\mathrm{FcB}_{2}$, mostrou um aumento de $1,75 \%$ na TEWL, com relação ao campo controle no mesmo intervalo.

\section{Discussão}

Os filmes desenvolvidos nesse trabalho apresentaram efeito de recuperação da barreira epidérmica, demonstrado pela diminuição da perda de água transepidermal $(3,4)$. Filmes cosméticos são capazes de formar uma matriz contínua de forma compacta na pele (5) e inibir a TEWL por oclusão; um dos mecanismos de hiadratação (24). Os hidratantes oclusivos reduzem a TEWL, criando uma barreira hidrofóbica sobre a pele e contribuindo para a matriz entre os corneócitos (24).

As formulações adicionadas de Caprilil Glicol, $\mathrm{FcB}_{1} \mathrm{e}$ FcAA, apresentaram reduções mais pronunciadas na TEWL em ambos os intervalos, mostrando melhores resultados como hidratantes do que as formulações em que este ingrediente não estava presente. Essa diminuição do TEWL em formulações com caprylyl glycol acontece porque este componente traz material graxo para a formulação filmógena, ocasionando emoliencia e contribuindo para a prevenção de perda de água superficial da pele (25). Isso ocorre porque na pele o fator que mais influência na perda de água é a composição e organização dos lipídios nos domínios extracelulares (26).

A diminuição da TEWL nas áreas em que as formulações adicionadas com caprilil glicol ou ácido hialurônico também pode ser explicada por sua atividade umectante $(10,12)$. Esses componentes atraem as moléculas de água para a superfície da pele $(3,4,10,12,16,17,27)$, onde essa água forma uma emulsão com os lipídios da pele e componentes do suor, diminuindo a TEWL (27).

No entanto, após 60 minutos, os valores de TEWL começam a retornar aos seus níveis basais devido, possivelmente, à absorção dos produtos. Além disso, sabe-se que a redução dos valores de TEWL pela aplicação de formulação tópica está relacionada à quantidade de produto, ao conteúdo graxo e o tipo de lipídeo presente na formulação (28). A adição de lipídeos com maiores comprimentos de cadeias carbônicas proporciona uma menor permeabilidade da barreira cutânea e menores valores de TEWL (29). Desse modo, dado que o CG trata-se de um álcool graxo com tamanho intermediáro 
Further studies may explore the effects of cosmetic films added with emollients composed of longer fatty chains and other combinations of humectants in preserving and improving skin barrier function.

\section{Conclusion}

According to the observed results, it can be concluded that all the studied cosmetic films presented moisturizing power. Both the presence of caprylyl glycol and the presence of hyaluronic acid influenced the transepidermal water loss. For future studies, the importance of humectant and emollient components, as well as the size of the emollient molecules, must be taken into consideration.

\section{Authors Contributions Statement}

IMBG, conceptualization and study design; data analysis; drafting, editing and reviewing; MMV, conceptualization and study design; experimental implementation; drafting, editing and reviewing; LMA, data analysis; drafting, editing and reviewing; GRL, conceptualization and study design; supervision and final writing.

\section{Funding}

This study was financed in part by the National Council for Scientific and Technological Development (CNPq).

\section{Acknowledgements}

The authors thank the Coordenação de Aperfeiçoamento de Pessoal de Nível Superior (CAPES) - Finance Code 0001, and National Council for Scientific and Technological Development (CNPq).

\section{Conflict of Interests}

The authors declare there are no financial and/or personal relationships that could present a potential conflict of interests. de cadeia carbônica, esse pode ter tido seu efeito emoliente reduzido após um maior período de tempo (T60).

Estudos futuros podem explorar os efeitos de filmes cosméticos adicionados de emolientes compostos por cadeias graxas maiores e outras combinações de umectantes na preservação e melhora da função da barreira cutânea.

\section{Conclusões}

De acordo com os resultados observados, pode-se concluir que todos os filmes cosméticos estudados apresentaram poder umectante. Tanto a presença de caprilil glicol quanto a presença de ácido hialurônico influenciaram na perda de água transepidérmica. Para estudos futuros a importância dos componentes umectantes e emolientes, assim como o tamanho da molécula do emoliente devem ser levados em consideração.

\section{Declaração sobre as contribuições do autores}

IMBG, conceção e desenho do estudo; análise de dados, redação, edição e revisão; MMV, conceção e desenho do estudo; implementação experimental; redação, edição e revisão; LMA, análise de dados; redação, edição e revisão; GRL, conceção e desenho do estudo; supervisão e redação final.

\section{Financiamento}

Esse estudo foi financiado pelo Conselho Nacional de Desenvolvimento Científico e Tecnológico (CNPq).

\section{Agradecimentos}

Agradecemos a Coordenação de Aperfeiçoamento de Pessoal de Nível Superior - Brasil (CAPES) - Código de Financiamento 001, a Fundação de Amparo à Pesquisa do Estado de São Paulo (FAPESP) e ao Conselho Nacional de Desenvolvimento Científico e Tecnológico (CNPq) pelo apoio financeiro.

\section{Conflito de Interesses}

Os autores declaram que não há relações financeiras e/ou pessoais que possam representar um potencial conflito de interesses. 


\section{References / Referências}

1. Mojumdar, E. H., Pham, Q. D., Topgaard, D., \& Sparr, E. (2017). Skin hydration: interplay between molecular dynamics, structure and water uptake in the stratum corneum. Scientific reports, 7(1), 15712. https://doi.org/10.1038/s41598-017-15921-5

2. Dos Santos, A. K. S. et al. (2019). A importância da hidratação da pele na resposta ao tratamento da flacidez cutânea utilizando radiofrequência. Científica do Ciesa, 148.

3. Spada, F., Barnes, T. M., \& Greive, K. A. (2018). Skin hydration is significantly increased by a cream formulated to mimic the skin's own natural moisturizing systems. Clinical, Cosmetic and Investigational Dermatology, 11, 491-497. https://doi.org/10.2147/ccid.s177697

4. Downie, J. B. (2010). Understanding moisturizers and their clinical benefits. Practical Dermatology for Pediatrics, September/October, 19-22.

5. Truiti, M. D. C. T., \& Sanfelice, A. M. (2010). Produtos em filme - Inovação na tecnologia de cosméticos. Acta Scientiarum. Health Science, 32(1). https://doi.org/10.4025/actascihealthsci.v32i1.6987

6. An, B., Lin, Y. S., \& Brodsky, B. (2016). Collagen interactions: Drug design and delivery. Advanced Drug Delivery Reviews, 97, 69-84. https:// doi.org/10.1016/j.addr.2015.11.013.

7. Lima, J.V., Moreira, M.N., Dos Santos, A.M., Brandão, M.R.S., De Aquino, A.A.(2020). Produção de Filme Ativo Adicionado de Óleo Essencial para Conservação de Queijos. Revista INGI-Indicação Geográfica e Inovação, 4 (2), 754-768.

8. Fratzl, P. (2008.). Collagen: Structure and Mechanics, an Introduction. In Collagen (pp. 1-13). Springer US. https://doi.org/10.1007/978-0-38773906-9_1

9. Manela-Azulay, M., Mandrim-de-Lacerda, C.; Perez, M.A., Filgueira, A.L.\& Cuzzi, T. (2003). Vitamina C / Vitamin C. Anais Brasileiros de Dermatologia, 3,265 .

10. Lee, D. H., Oh, I. Y., Koo, K. T., Suk, J. M., Jung, S. W., Park, J. O., Kim, B. J., \& Choi, Y. M. (2014). Improvement in skin wrinkles using a preparation containing human growth factors and hyaluronic acid serum. Journal of Cosmetic and Laser Therapy, 17(1), 20-23. https://doi.org $/ 10.3109 / 14764172.2014 .968577$

11. Belvedere, R., Bizzarro, V., Parente, L., Petrella, F., \& Petrella, A. (2018). Effects of Prisma ${ }^{\circledR}$ Skin dermal regeneration device containing glycosaminoglycans on human keratinocytes and fibroblasts. Cell adhesion \& migration, 12(2), 168-183. https://doi.org/10.1080/19336918.20 17.1340137

12. Papakonstantinou, E., Roth, M., \& Karakiulakis, G. (2012). Hyaluronic acid: A key molecule in skin aging. Dermato-Endocrinology, 4(3), 253-258. https://doi.org/10.4161/derm.21923

13. Rossi, S., Mori, M., Vigani, B., Bonferoni, M. C., Sandri, G., Riva, F., Caramella, C., \& Ferrari, F. (2018). A novel dressing for the combined delivery of platelet lysate and vancomycin hydrochloride to chronic skin ulcers: Hyaluronic acid particles in alginate matrices. European Journal of Pharmaceutical Sciences, 118, 87-95. https://doi.org/10.1016/j.ejps.2018.03.024

14. Iacopetti, I., Perazzi, A., Martinello, T., Gemignani, F., \& Patruno, M. (2020). Hyaluronic acid, Manuka honey and Acemannan gel: Woundspecific applications for skin lesions. Research in Veterinary Science, 129, 82-89. https://doi.org/10.1016/j.rvsc.2020.01.009

15. Imai, Y., Usui, T., Matsuzaki, T., Yokotani, H., \& Mima, H. (1967). The antiscorbutic activity of L-ascorbic acid phosphate given orally and percutaneously in guinea pigs. Japanese journal of pharmacology, 17(2), 317-324. https://doi.org/10.1254/jjp.17.317

16. Lawan, K., Kanlayavattanakul, M., Lourith, N. (2009). Antimicrobial efficacy of caprylyl glycol and ethylhexylglycerine in emulsion. Journal of Health Research, 23 (1), 1-3.

17. Ziosi, P., Manfredini, S., Vandini, A. \& Vertuani, S. (2013). Caprylyl glycol/phenethyl alcohol blend for alternative preservation of cosmetics. Cosmetics \& Toiletries, $128,538-551$.

18. Jansen van Rensburg, S., Franken, A., \& Du Plessis, J. L. (2019). Measurement of transepidermal water loss, stratum corneum hydration and skin surface $\mathrm{pH}$ in occupational settings: A review. Skin Research and Technology, 25(5), 595-605. https://doi.org/10.1111/srt.1271.

19. Roy, S., \& Rhim, J.-W. (2020). Preparation of carbohydrate-based functional composite films incorporated with curcumin. Food Hydrocolloids, 98, 105302. https://doi.org/10.1016/j.foodhyd.2019.105302

20. Berardesca, E., \& European Group for Efficacy Measurements on Cosmetics and Other Topical Products (EEMCO) (1997). EEMCO guidance for the assessment of stratum corneum hydration: electrical methods. Skin research and technology : official journal of International Society for Bioengineering and the Skin (ISBS) [and] International Society for Digital Imaging of Skin (ISDIS) [and] International Society for Skin Imaging (ISSI), 3(2), 126-132. https://doi.org/10.1111/j.1600-0846.1997.tb00174.x

21. Rogiers, V. (2001) EEMCO guidance for the assessment of transepidermal water loss in cosmetic sciences. Skin research and technology : official journal of International Society for Bioengineering and the Skin (ISBS) [and] International Society for Digital Imaging of Skin (ISDIS) [and] International Society for Skin Imaging (ISSI), 14 (2), 117-128.

22. Capitani, R. D., Mercurio, D., Camargo Junior, F. B., \& B. G. Maia Campos, P. M. (2012). Stability and Clinical Efficacy of Moisturizing Cosmetic Formulations Containing Vitamins C and E. Biomedical and Biopharmaceutical Research, 9(2), 215-224. https://doi.org/10.19277/ bbr.9.2.44

23. Bazin, R., \& Fanchon, C. (2006). Equivalence of face and volar forearm for the testing of moisturizing and firming effect of cosmetics in hydration and biomechanical studies. International journal of cosmetic science, 28(6), 453-460. https://doi.org/10.1111/j.1467-2494.2006.00352.x.

24. Kraft, J. N., \& Lynde, C. W. (2005). Moisturizers: what they are and a practical approach to product selection. Skin therapy letter, 10(5), 1-8.

25. Correa, M. (2012) Cosmetologia: ciência e técnica. Medfarma, 67.

26. Lodén M. (2003). Role of topical emollients and moisturizers in the treatment of dry skin barrier disorders. American journal of clinical dermatology, 4(11), 771-788. https://doi.org/10.2165/00128071-200304110-00005

27. Gil-Castaño, G., \& Cardona, R. (2020). Emolientes: beneficios, elementos clave y aplicación clínica. Revista alergia Mexico, 67, 128-141. https://doi.org/10.29262/ram.v67i2.730.

28. Buraczewska, I., Broström, U., \& Lodén, M. (2007). Artificial reduction in transepidermal water loss improves skin barrier function. British Journal of Dermatology, 157(1), 82-86. https://doi.org/10.1111/j.1365-2133.2007.07965.x

29. Petry, T., Bury, D., Fautz, R., Hauser, M., Huber, B., Markowetz, A., Mishra, S., Rettinger, K., Schuh, W., \& Teichert, T. (2017). Review of data on the dermal penetration of mineral oils and waxes used in cosmetic applications. Toxicology letters, 280, 70-78. https://doi.org/10.1016/j. toxlet.2017.07.899 